\title{
Biometry of Pityrocarpa moniliformis seeds using digital imaging: implications for studies of genetic divergence
}

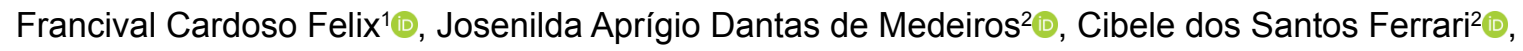
Fábio de Almeida Vieira² ${ }^{2}$, Mauro Vasconcelos Pachecoº

\footnotetext{
${ }^{1}$ Universidade Federal do Paraná, Departamento de Engenharia Florestal, Curitiba-PR, Brasil. E-mail: francival007@gmail.com

2 Universidade Federal do Rio Grande do Norte, Unidade Especializada em Ciências Agrárias, Macaíba-RN, Brasil. E-mail: josi-nilda@hotmail.com; cibeferrari@hotmail.com; vieirafa@gmail.com; pachecomv@hotmail.com
}

ABSTRACT: Pityrocarpa moniliformis is a tree species with socioeconomic potential in semiarid regions. The objective of this work was to perform the biometry of $P$. moniliformis seeds with digital processing of images as subsidies for studies of genetic divergence. For this, we executed the biometric analysis of the seeds from 33 adult trees using digital image processing. Subsequently, descriptive and correlation analyses were performed between the biometric variables, as well as the multivariate analysis of principal components and the Euclidean distance. Digital image processing is efficient in assessing biometric differences among adult trees which vary in the morphological and biometric aspects. The biometric variables quantified employing digital images are efficient in the distinction of the adult trees. For this reason, they are important morphological markers that can aid in the differentiation of genotypes of $P$. moniliformis and contribute to studies of genetic divergence.

\section{Biometria de sementes de Pityrocarpa moniliformis utilizando imagens digitais: implicações para estudos de divergência genética}

RESUMO: Pityrocarpa moniliformis é uma espécie arbórea que possui potencial socioeconômico em regiões semiáridas. 0 objetivo deste trabalho foi realizar a biometria de sementes de $P$. moniliformis por meio do processamento digital de imagens como subsídios para estudos de divergência genética. Para isso, realizou-se a análise biométrica das sementes de 33 matrizes por meio do processamento digital de imagens. Em seguida, procederam-se as análises descritivas e de correlação entre as variáveis biométricas, bem como análise de variância multivariada das componentes principais e de distância Euclidiana. $\mathrm{O}$ processamento digital de imagens é eficiente em detectar diferenças biométricas entre sementes de matrizes, as quais possuem variação dos aspectos morfológicos e biométricos entre as diferentes árvores. As variáveis biométricas quantificadas por meio de imagens digitais são eficazes na distinção das sementes de matrizes, sendo assim, são importantes marcadores morfológicos que podem auxiliar na diferenciação de genótipos de $P$. moniliformis e contribuir para estudos de divergência genética.

Palavras-chave: distância Euclidiana; descritores morfológicos; componentes principais; análise de sementes 


\section{Introduction}

Pityrocarpa moniliformis (Benth.) Luckow \& R. W. Jobson., Fabaceae, is an arboreal forest species occurring in northeastern Brazil (Maia-Silva et al., 2012) and used for the recovery of degraded areas, as firewood supply and as animal feed (Azerêdo et al., 2011). It also has potential in beekeeping (Alves et al., 2014) and is among the tree species of the Brazilian semiarid that contributes most to the honey supply (Jesus et al., 2015).

Perennial species can be genetically characterised with the help of botanical and morphological descriptors (Costa et al., 2016). Thus, biometric seed analysis can contribute to the study of divergence and genetic variability between populations and individuals of the same species, providing subsidies for the selection of superior traits and genotypes that can be further improved (Cruz et al., 2012).

Biometric seed analysis can provide important results for the conservation and exploration of native forest species, thereby contributing to reforestation and genetic improvement programs. Besides, it can be used as an essential tool for detecting inter- and intrapopulation divergences resulting from environmental or genetic variations (Vieira \& Gusmão, 2008). Despite the importance of these studies aiming at genetic variability between individuals and populations, research regarding seed biometrics in native forest essences, using this approach is still not common.

The use of fast and efficient methods, such as digital seed surface image analysis and processing techniques, has certain advantages over traditional manual methods (Varma et al., 2013). Manual techniques are limited to a few variables, requiring a relatively long time to measure seed biometric characteristics and are more susceptible to measurement errors. In constrast, digital image processing provides a variety of information quickly and efficiently and with a more significant number of seeds as sample units.

In this sense, computerised analysis of seed images is used for biometric and morphological characterisation to obtain quantitative data from numerous descriptors or morphometric parameters (Orrù et al., 2012) which correlate with genetic characteristics (Varma et al., 2013) and contributes to the identification of genotypes from different regions (Medina et al., 2010). In addition to supporting studies of taxonomy, cataloging and conservation of species (Ucchesu et al., 2016), this approach can also be used to discriminate species of the same genus through the development of programs (software) (Bacchetta et al., 2008), contributing to the analysis of seed physiological quality (Dell'Aquila, 2006).

Given the economic and ecological potential of $P$. moniliformis for the semiarid region of Northeastern Brazil, the objective of this work was to perform biometrics of $P$. moniliformis seeds through digital image processing as subsidies for studies of genetic divergence.

\section{Material and Methods}

\section{Study area and seed acquisition}

Semi-open fruits (brown color) attached to $P$. moniliformis trees were collected directly from 33 individuals at least two and a half times their height apart (Sebbenn, 2002), in two locations [19 in Macaíba (5 ${ }^{\circ} 53^{\prime} 53.06^{\prime \prime} \mathrm{S}$ and 35 $21^{\prime} 39.47^{\prime \prime} \mathrm{W}$ ) and 14 in Mossoró ( $5^{\circ} 03^{\prime} 34.51^{\prime \prime}$ S e $37^{\circ} 23^{\prime} 56.92^{\prime \prime}$ W)] from Rio Grande do Norte State, Brazil (Figure 1), between August and November 2017.

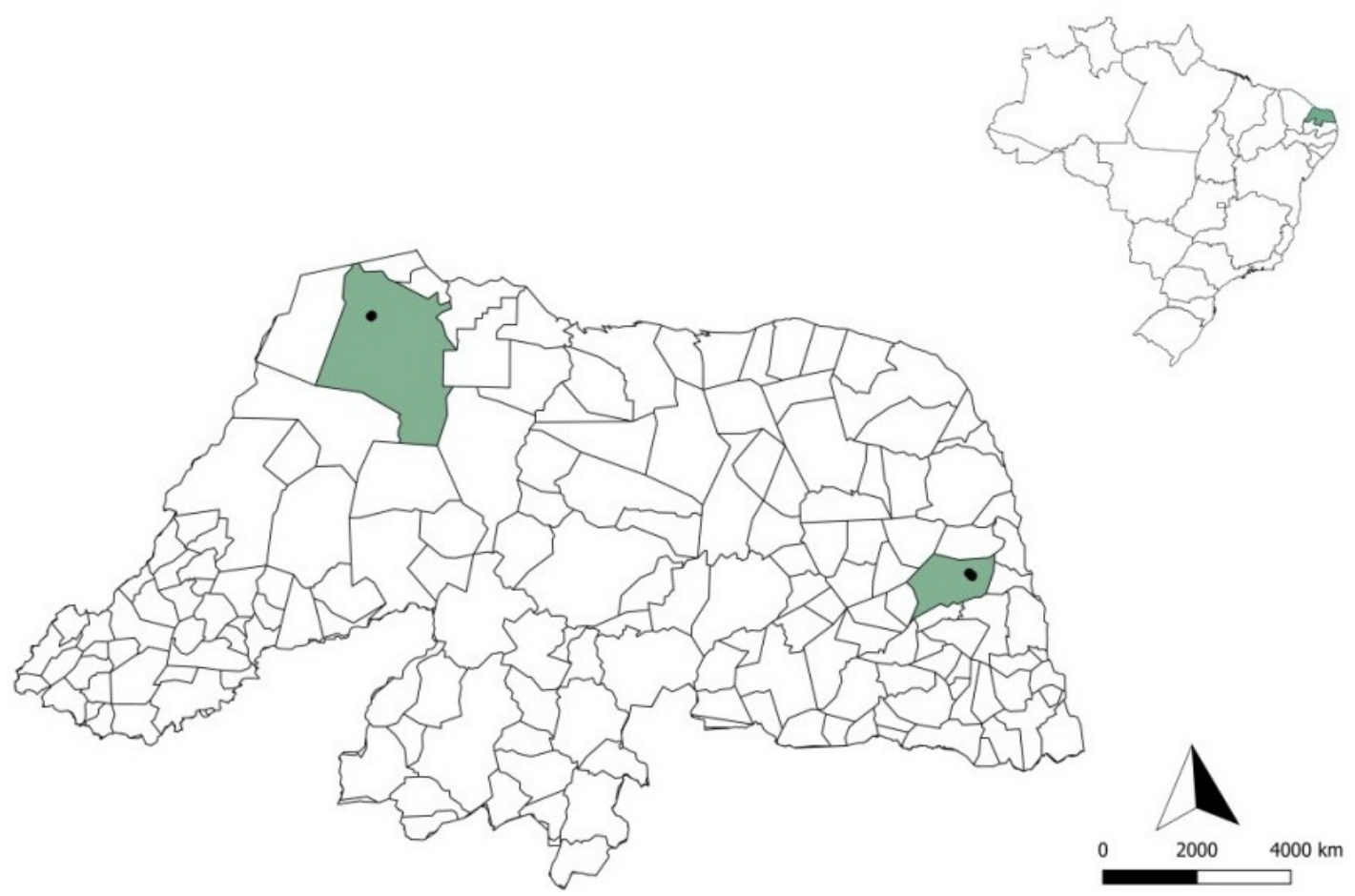

Figure 1. Location of populations in Macaíba (east) and Mossoró (west), Rio Grande do Norte State, Brazil. 
Seed were processed at the Laboratório de Sementes Florestais of the Unidade Acadêmica Especializada em Ciências Agrárias/Universidade Federal do Rio Grande do Norte (UAECIA/UFRN). Subsequently, seeds of each adult trees were photographed and biometrically analysed by digital image processing.

\section{Seed biometrics with image processing}

The software ImageJ $^{\circledR}$ version 1.46 (Ferreira \& Rasband, 2012) was used for seed biometrics digital image editing. For this, 400 seeds from each adult tree were photographed with a 12-mp lens at a distance of $20 \mathrm{~cm}$ on a matte black paper background marked with a millimetre-sized ruler as a reference metric. We analysed the following biometric parameters: area $\left(\mathrm{mm}^{2}\right)$; perimeter $(\mathrm{mm})$; circularity (0.0-1.0); length $(\mathrm{mm})$; width $(\mathrm{mm})$, aspect ratio; roundness (0.0-1.0) and solidity (0.0-1.0) of the seed (Table 1 ).

Image processing was based on capture (Figure 2A) and conversion to the 8-bit format (256 tones) (Figure 2B), followed by image scale calibration in millimetres, selection of

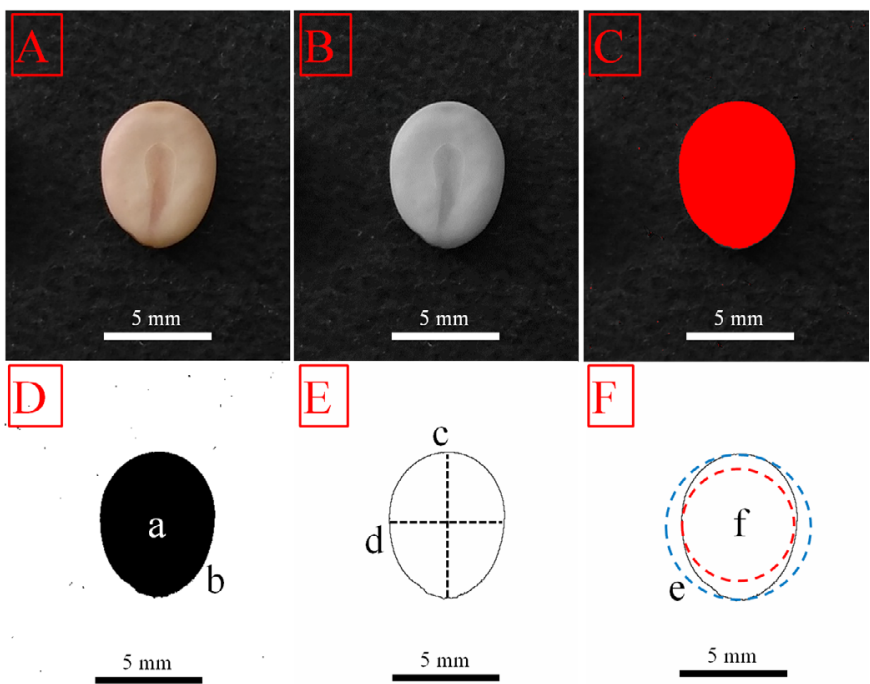

Figure 2. Digital image processing steps to obtain biometric data in $P$. moniliformis seeds. A: photo capture; B: conversion to 8-bit format; C: use of "threshold" mask; D: biometric analysis [area (a), perimeter (b) and e solidity (area/convex area)]; E: length (c), width (d) and aspect ratio (c/d), F: circularity (e) and roundness ( $f$ ) of seed. the area to be analysed, and use of the "threshold" mask for contrast differentiation between image components (Figure $2 \mathrm{C}$ ). Finally, the seeds were biometrically analysed (Figures 2D, 2E and 2F) and the results were exported in Excel $^{\circ}$ format.

\section{Experimental design and data analysis}

The experimental design was completely randomised with 400 seeds per adult trees. The seed biometrics data of the 33 adult trees (totalling 13,200 seeds) were submitted to Lilliefors residual normality tests ( $1 \%$ probability level), descriptive statistics and analysis of variance by the $\mathrm{F}$ test, with means being compared by the Scott-Knott test at the $5 \%$ probability level. Subsequently, Pearson's simple correlation $\left(r_{p}\right)$ was performed among all biometric parameters evaluated at the $1 \%$ probability level by the t-test. The statistical program used was BioEstat ${ }^{\circ}$ (version 5.3) (Ayres et al., 2007).

Multivariate analysis of variance of the principal components was performed with standardised data ( $\mathrm{x}$ average/standard deviation), obtaining eigenvalue and variance results for the contribution of each principal component and distance between the trees, eliminating unrepresentative components. The statistical program used for this analysis was Past ${ }^{\circledR}$ (version 3.20) (Hammer \& Harper, 2008).

Finally, Euclidean distance matrix analysis was performed for the genotypes, followed by the elaboration of a hierarchical dendrogram of similarity UPGMA (Unweighted Pair Group Method with Arithmetic mean), with the normalised group mean for the biometric parameters. The statistical program used was BioEstat (version 5.3) (Ayres et al., 2007).

\section{Results and Discussion}

Morphological characteristics of seeds are generally used to identify species or varieties (Maranho et al., 2014). For the $P$. moniliformis seeds, there was variation in the predominant shape and size, colour and brightness of the integument, shape and colouration of the pleurogram (shown in Figure 3), evidencing that there are differences of these characteristics within the same species and between individuals of the same locality (Figure 3).

P. moniliformis seeds showed morphological (Figure 3) and biometric (Table 2 ) variation among seeds from different

Table 1. Description of biometric variables used in digital image processing in $P$. moniliformis seeds.

\begin{tabular}{|c|c|}
\hline Variable & Description \\
\hline Area & Seed selection area in calibrated square units, calculated within the perimeterdefined polygon $\left(\mathrm{mm}^{2}\right)$. \\
\hline Perimeter & $\begin{array}{l}\text { Length of the external limit of seed selection in calibrated square units, calculated from the centres of thelimit pixels } \\
(\mathrm{mm}) \text {. }\end{array}$ \\
\hline Length & Greater distance between two points along the seed selection limitin calibrated square units (mm). \\
\hline Width & The smallest distance between two points along the seed selection limit in calibrated square units ( $\mathrm{mm}$ ). \\
\hline Roundness & $\begin{array}{l}\text { Scalar value from } 0.0 \text { to } 1.0 \text {, indicating a perfect circle when close to } 1.0 \text { for the seed shape relative to the major axis } \\
4 \times\left([\text { Area] } / \pi \text {. [Major axis }]^{2}\right) \text {. }\end{array}$ \\
\hline Solidity & Scalar value from 0.0 to 1.0 , indicated concerning seed convex area selection[Area]/[Convex area]. \\
\hline
\end{tabular}



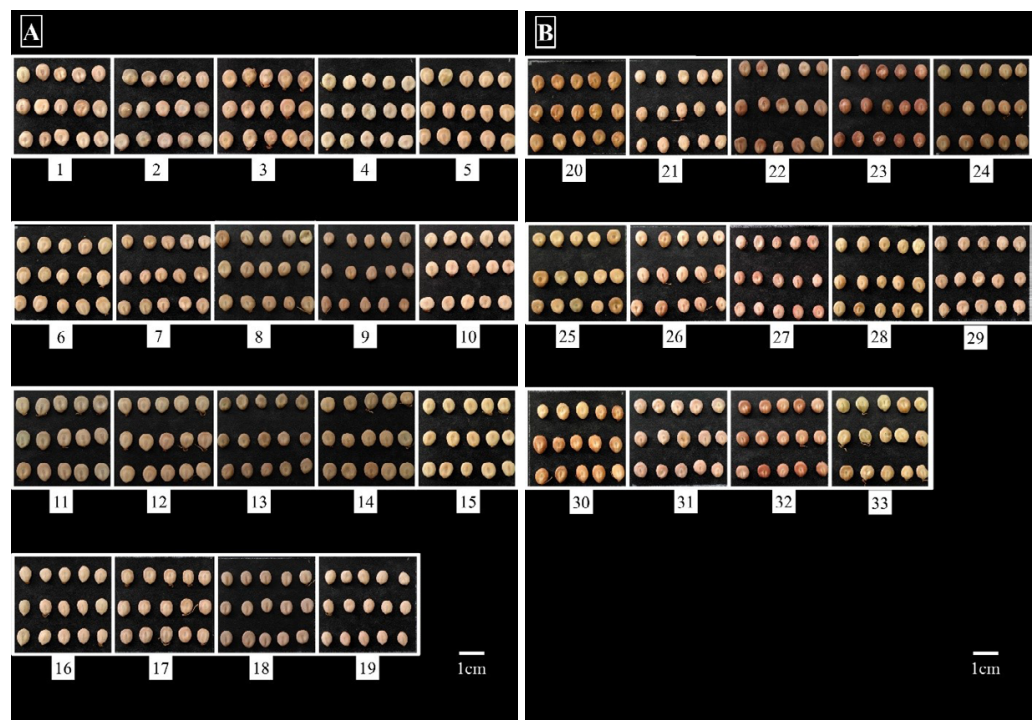

Figure 3. Morphological characteristics of seeds from P. moniliformis adult trees collected at Macaíba (A) and Mossoró (B) localities, Rio Grande do Norte State, Brazil.

Table 2. Biometric aspects (area, perimeter, circularity, length, width, aspect ratio - AR, roundness and solidity) of $P$. moniliformis seeds analysed with the digital imaging, collected at Macaíba (1-19) and Mossoró (20-33) localities, Rio Grande do Norte State, Brazil.

\begin{tabular}{|c|c|c|c|c|c|c|c|c|}
\hline \multirow{2}{*}{ Tree } & \multirow{2}{*}{$\begin{array}{l}\text { Area** } \\
\left(\mathrm{mm}^{2}\right)\end{array}$} & \multirow{2}{*}{$\begin{array}{c}\begin{array}{c}\text { Perimeter }{ }^{* *} \\
(\mathrm{~mm})\end{array}\end{array}$} & \multirow{2}{*}{$\begin{array}{c}\text { Circularity }^{* *} \\
(0.0-1.0)\end{array}$} & Length $^{* *}$ & Width $^{* *}$ & \multirow{2}{*}{$\mathrm{AR}^{* *}$} & Roundess** & Solidity" \\
\hline & & & & \multicolumn{2}{|c|}{$(\mathrm{mm})$} & & \multicolumn{2}{|c|}{$(0.0-1.0)$} \\
\hline 1 & $21.9 \mathrm{~m}$ & $19.1 \mathrm{i}$ & $0.787 i$ & $6.0 p$ & $4.9 \mathrm{~m}$ & $1.20 \mathrm{e}$ & $0.839 \mathrm{f}$ & $0.958 b$ \\
\hline 2 & $24.2 \mathrm{j}$ & $20.2 \mathrm{f}$ & $0.768 \mathrm{j}$ & $6.1 \mathrm{~m}$ & $5.3 \mathrm{~g}$ & $1.13 \mathrm{~g}$ & $0.893 a$ & $0.954 \mathrm{c}$ \\
\hline 3 & $31.6 \mathrm{~b}$ & $22.8 \mathrm{a}$ & $0.775 \mathrm{j}$ & $7.4 \mathrm{a}$ & $5.9 \mathrm{a}$ & $1.24 \mathrm{~d}$ & $0.809 \mathrm{i}$ & $0.959 b$ \\
\hline 4 & $24.7 i$ & $19.0 i$ & $0.865 b$ & $6.3 \mathrm{k}$ & $5.3 \mathrm{~g}$ & $1.15 \mathrm{~g}$ & $0.869 c$ & $0.970 a$ \\
\hline 5 & $28.2 c$ & $21.1 \mathrm{c}$ & $0.813 \mathrm{~g}$ & $6.9 c$ & $5.6 \mathrm{c}$ & $1.19 \mathrm{e}$ & $0.846 \mathrm{e}$ & $0.960 \mathrm{~b}$ \\
\hline 6 & $27.0 \mathrm{e}$ & $20.6 d$ & $0.819 \mathrm{f}$ & $6.7 \mathrm{~d}$ & $5.5 \mathrm{e}$ & $1.19 \mathrm{e}$ & 0.845 e & $0.962 b$ \\
\hline 7 & 22.51 & $18.1 \mathrm{I}$ & $0.859 \mathrm{~b}$ & $5.9 r$ & $5.1 \mathrm{k}$ & $1.14 \mathrm{~g}$ & $0.876 \mathrm{~b}$ & $0.966 a$ \\
\hline 8 & $23.0 \mathrm{k}$ & $18.6 \mathrm{j}$ & $0.846 \mathrm{c}$ & $6.3 \mathrm{k}$ & 5.01 & $1.23 \mathrm{~d}$ & $0.818 \mathrm{~h}$ & $0.966 a$ \\
\hline 9 & $16.5 \mathrm{q}$ & 16.10 & $0.814 \mathrm{~g}$ & $5.5 \mathrm{~s}$ & $4.1 \mathrm{t}$ & $1.30 \mathrm{c}$ & $0.776 \mathrm{k}$ & $0.958 \mathrm{~b}$ \\
\hline 10 & $24.3 j$ & $18.8 \mathrm{j}$ & $0.865 b$ & 6.21 & $5.3 \mathrm{~h}$ & $1.15 \mathrm{~g}$ & $0.872 c$ & $0.969 a$ \\
\hline 11 & $32.2 \mathrm{a}$ & $22.4 \mathrm{~b}$ & $0.813 \mathrm{~g}$ & $7.4 \mathrm{a}$ & $5.8 \mathrm{~b}$ & $1.24 \mathrm{~d}$ & $0.806 \mathrm{i}$ & $0.965 \mathrm{~b}$ \\
\hline 12 & $27.5 \mathrm{~d}$ & $20.8 d$ & $0.821 \mathrm{f}$ & $6.7 \mathrm{~d}$ & $5.6 \mathrm{~d}$ & $1.18 \mathrm{f}$ & $0.853 \mathrm{e}$ & $0.963 b$ \\
\hline 13 & $24.7 \mathrm{i}$ & $19.4 \mathrm{~h}$ & $0.827 \mathrm{e}$ & $6.6 \mathrm{e}$ & $5.1 \mathrm{k}$ & $1.28 \mathrm{c}$ & $0.786 j$ & $0.962 b$ \\
\hline 14 & $27.3 d$ & $20.2 f$ & $0.852 c$ & $6.6 \mathrm{e}$ & $5.6 \mathrm{~d}$ & $1.16 \mathrm{f}$ & $0.863 d$ & $0.968 a$ \\
\hline 15 & $22.0 \mathrm{~m}$ & 17.91 & $0.866 \mathrm{a}$ & $6.0 p$ & $4.9 \mathrm{~m}$ & $1.20 \mathrm{e}$ & $0.835 \mathrm{f}$ & $0.969 a$ \\
\hline 16 & $20.9 n$ & $17.8 \mathrm{~m}$ & $0.830 \mathrm{e}$ & $6.3 \mathrm{j}$ & $4.6 \mathrm{q}$ & $1.35 \mathrm{a}$ & $0.751 \mathrm{n}$ & $0.964 b$ \\
\hline 17 & $24.1 \mathrm{j}$ & $19.6 \mathrm{~g}$ & $0.820 \mathrm{f}$ & $6.5 \mathrm{~g}$ & $5.0 \mathrm{~m}$ & $1.28 \mathrm{c}$ & $0.782 \mathrm{k}$ & $0.960 \mathrm{~b}$ \\
\hline 18 & $23.0 \mathrm{k}$ & $18.3 \mathrm{k}$ & $0.868 a$ & $6.1 \mathrm{~m}$ & $5.0 \mathrm{~m}$ & $1.22 \mathrm{~d}$ & $0.822 \mathrm{~h}$ & $0.969 a$ \\
\hline 19 & 19.70 & $17.3 \mathrm{n}$ & $0.834 \mathrm{e}$ & $6.1 \mathrm{n}$ & $4.5 r$ & $1.32 \mathrm{~b}$ & 0.765 I & $0.964 b$ \\
\hline 20 & $26.3 \mathrm{f}$ & $20.5 \mathrm{e}$ & $0.795 \mathrm{~h}$ & $7.0 \mathrm{~b}$ & $5.3 \mathrm{i}$ & $1.30 \mathrm{c}$ & 0.7741 & $0.959 b$ \\
\hline 21 & $19.0 \mathrm{p}$ & $17.3 \mathrm{n}$ & $0.810 \mathrm{~g}$ & 6.00 & $4.3 \mathrm{~s}$ & $1.37 \mathrm{a}$ & $0.733 \circ$ & $0.959 b$ \\
\hline 22 & $21.0 n$ & $17.7 \mathrm{~m}$ & $0.844 d$ & $6.1 \mathrm{~m}$ & $4.7 p$ & $1.29 \mathrm{c}$ & $0.778 \mathrm{k}$ & $0.963 b$ \\
\hline 23 & $22.8 \mathrm{k}$ & $18.6 \mathrm{j}$ & $0.824 \mathrm{f}$ & $6.4 \mathrm{i}$ & $4.9 n$ & $1.29 \mathrm{c}$ & $0.778 \mathrm{k}$ & $0.961 b$ \\
\hline 24 & $25.6 \mathrm{~g}$ & $19.6 \mathrm{~g}$ & $0.845 d$ & $6.5 f$ & $5.4 \mathrm{f}$ & $1.18 \mathrm{f}$ & $0.848 \mathrm{e}$ & $0.964 b$ \\
\hline 25 & $25.0 \mathrm{~h}$ & $19.3 \mathrm{~h}$ & $0.852 \mathrm{c}$ & 6.21 & $5.4 \mathrm{f}$ & $1.15 \mathrm{~g}$ & $0.875 \mathrm{c}$ & $0.966 a$ \\
\hline 26 & $23.0 \mathrm{k}$ & $19.1 \mathrm{i}$ & $0.804 \mathrm{~h}$ & $6.5 \mathrm{f}$ & 4.80 & $1.32 b$ & $0.762 \mathrm{~m}$ & $0.961 b$ \\
\hline 27 & $16.2 r$ & $16.0 \mathrm{o}$ & $0.802 \mathrm{~h}$ & $5.4 \mathrm{t}$ & $4.1 \mathrm{t}$ & $1.29 \mathrm{c}$ & $0.782 \mathrm{k}$ & $0.956 b$ \\
\hline 28 & $20.8 \mathrm{n}$ & $17.7 \mathrm{~m}$ & $0.833 \mathrm{e}$ & $6.1 \mathrm{n}$ & $4.7 p$ & $1.29 c$ & $0.777 \mathrm{k}$ & $0.963 b$ \\
\hline 29 & $22.0 \mathrm{~m}$ & $18.3 \mathrm{k}$ & $0.832 \mathrm{e}$ & 6.00 & $5.0 \mathrm{~m}$ & $1.19 \mathrm{e}$ & $0.841 \mathrm{f}$ & $0.965 b$ \\
\hline 30 & $24.7 i$ & $19.5 \mathrm{~h}$ & $0.816 f$ & $6.7 \mathrm{~d}$ & 5.01 & $1.33 b$ & $0.756 \mathrm{~m}$ & $0.964 b$ \\
\hline 31 & $24.3 \mathrm{j}$ & $19.2 \mathrm{i}$ & $0.837 d$ & $6.4 \mathrm{~h}$ & $5.2 \mathrm{j}$ & $1.21 \mathrm{e}$ & $0.832 \mathrm{~g}$ & $0.967 a$ \\
\hline 32 & 22.31 & $18.3 \mathrm{k}$ & $0.841 \mathrm{~d}$ & $6.0 \mathrm{q}$ & 5.01 & $1.18 \mathrm{f}$ & $0.850 \mathrm{e}$ & $0.965 b$ \\
\hline 33 & $24.5 \mathrm{i}$ & $19.8 \mathrm{~g}$ & $0.806 \mathrm{~g}$ & $6.4 \mathrm{~h}$ & $5.2 \mathrm{i}$ & $1.18 \mathrm{f}$ & 0.847 e & $0.959 b$ \\
\hline Average & 23.7 & 19.1 & 0.827 & 6.3 & 5.1 & 1.23 & 0.816 & 0.963 \\
\hline CV (\%) & $19.0 \%$ & 13.2 & 12.0 & 10.0 & 10.9 & 8.3 & 7.9 & 2.0 \\
\hline
\end{tabular}

" Significant at the $1 \%$ probability level by the $\mathrm{F}$ test. Averages followed by the same letter in the column are statistically similar by the Scott-Knott test at the $5 \%$ probability level. $\mathrm{CV}$ : coefficient of variation. 
trees, indicating differences in seed production that may be due to the environmental or genetic factors.

Changes in the seed coat colour of this species, shown in Figure 3, also suggest different intensities of integument dormancy, which may be associated with the cellular and biochemical constitution of the protective seed coat (Bewley et al., 2013). Biometric variations in seed size and shape are related to the germination capacity of the species and to its ability to settle in the environment, directly influencing population dynamics (Costa et al., 2016).

The biometric aspects analysed with image processing provided phenotypic characteristics of seed size and shape (Table 2), which showed that trees of the same species produce seeds with different predominant dimensions due to phenotypic variations. These changes can be grouped to classify seeds and to reveal patterns of similarity between the trees.

For the production of agricultural seeds, it is preferable to choose uniform lots with larger seeds, which are more likely to germinate and form vigorous seedlings, mainly due to the nutritional status of the embryos with the largest reserve (Marcos Filho, 2016).

However, physical characteristics may not be directly associated with seed physiological quality for all species (Peñaloza \& Durán, 2015), especially for forest essences, since for forest species, genetic variability is not acquired by obtaining only larger seeds.

Seed biometrics fitted to the normal distribution for the residues of the analysed variables ( $1 \%$ probability). The standard error was below 0.2 for area and perimeter, 0.02 for length, width and aspect ratio and 0.009 for circularity, roundness and solidity of seeds.

Low standard error values indicate that the average accurately represents the actual values of the dataset, and the coefficient of variation found was below $20 \%$ (Table 2), showing the accuracy of the experiment when these parameters are respected (Menegatti et al., 2017). The efficiency and precision of the analyses are associated with the biometrics method employed and the high sample number adopted, which is only feasible with the use of computerised image analysis.

Seed biometric characteristics has a significant effect on $71 \%$ of the correlations (20 of 28) (Table 3). Also, a strong linear correlation coefficient $\left(r_{p}\right)$ was observed between area and length (0.914), area and width (0.941), perimeter and circularity (-0.738), length and solidity (0.888), length and width (0.768) and aspect ratio and roundness $(-0.993)$ of $P$. moniliformis seeds. Therefore, seeds of this species with a larger area, occasionally also larger, have a greater length, width and proportion and are more circular concerning the perimeter and its major axis.

However, it is important to analyse, through simplified and precise mathematical functions, which of these variables represents the most significant variation of the data. For this, multivariate analysis studies of the main components are employed. This analysis aims to demonstrate the main trends of data variations present in the variables to verify the divergence between the adult trees (Costa et al., 2016).

The study of the principal components and the arrangement of cluster models are multivariate analyses that can be used to estimate the divergence between adult trees, based on morphophysiological variations in plants, fruits and seeds (Menegatti et al., 2017). For this, the first three principal components represented approximately $98 \%$ the variation of data analysed; however, principal components $1(45.2 \%)$ and $2(34.0 \%)$ were selected as sufficient and adequate to explain the data in about $79.2 \%$ of the total variation (Table 4).

For the selection of the principal components, it is important to choose those that have an eigenvalue greater than 1.0 (Kaiser, 1960) and that concentrate the most significant variation of the data so that it is acceptable to perform a divergent grouping between genotypes (Cruz et al., 2011). Values above $70 \%$ for the first major components are adequate to explain the total variance between variables (Medina et al., 2010).

The contribution of the variances found in each variable to the principal components was different, with area (19\%), perimeter $(19 \%)$, length $(18 \%)$ and width $(19 \%)$ of the seeds contributing $76 \%$ to component 1 , while circularity (18\%), aspect ration (19\%), roundness $(19 \%)$ and solidity $(17 \%)$ of the seeds contributed $73 \%$ to component 2 (Table 5 ). These results indicate that all biometric variables influence the variability among $P$. moniliformis individuals analysed with digital seed image processing. Similar to seeds, fruit characteristics also contribute as morphological markers to analysis, identification and genotype grouping (Souza et al., 2017). However, this species has dehiscent fruits, which impedes accurate biometrics through this image analysis method.

Plotting of the adult trees revealed which of them were more distant from each other and between the axes of the

Table 3. Pearson's linear correlation matrix $\left(r_{p}\right)$ for biometric aspects (area - A, perimeter - P, circularity - C, length - L, width - W, aspect ratio - AR, roundness - R and solidity - $S$ ) of $P$. moniliformis seeds analysed with digital imaging.

\begin{tabular}{|c|c|c|c|c|c|c|c|c|}
\hline & A & $\mathbf{P}$ & C & $\mathbf{L}$ & W & $\overline{A R}$ & $\mathbf{R}$ & $S$ \\
\hline$A$ & 1,000 & --- & --- & --- & --- & --- & --- & --- \\
\hline$P$ & $0.578^{* *}$ & 1.000 & --- & --- & --- & --- & --- & --- \\
\hline C & $0.061 \mathrm{~ns}$ & $-0.738^{* *}$ & 1.000 & --- & --- & --- & --- & --- \\
\hline$W$ & $0.941^{* *}$ & $0.590^{* *}$ & $0.016^{n s}$ & $0.768^{* *}$ & 1.000 & --- & --- & --- \\
\hline$A R$ & -0.072 ns & $0.035^{\mathrm{ns}}$ & $-0.148^{* *}$ & $0.274^{* *}$ & $-0.366^{* *}$ & 1.000 & --- & --- \\
\hline $\mathrm{R}$ & $0.060^{\mathrm{ns}}$ & $-0.035 \mathrm{~ns}$ & $0.133^{* *}$ & $-0.285^{* *}$ & $0.358^{* *}$ & $-0.993^{* *}$ & 1.000 & --- \\
\hline
\end{tabular}

${ }^{n s}$ not significant and " significant at the $1 \%$ probability level. 
Table 4. Eigenvalues and eigenvectors of the principal components obtained from multivariate analysis of biometric variables with digital imaging in P. moniliformis seeds.

\begin{tabular}{ccccc}
\hline Factor & Eigenvalue & $\begin{array}{c}\text { Total } \\
\text { variance (\%) }\end{array}$ & $\begin{array}{c}\text { Accumulated } \\
\text { eigenvalue }\end{array}$ & $\begin{array}{c}\text { Accumulated } \\
\text { total variance (\%) }\end{array}$ \\
\hline 1 & 3.618 & 45.229 & 3.62 & 45.23 \\
2 & 2.718 & 33.969 & 6.34 & 79.20 \\
3 & 1.485 & 18.563 & 7.82 & 97.76 \\
4 & 0.119 & 1.485 & 7.94 & 99.25 \\
5 & 0.027 & 0.331 & 7.97 & 99.58 \\
6 & 0.019 & 0.231 & 7.98 & 99.81 \\
7 & 0.009 & 0.107 & 7.99 & 99.92 \\
8 & 0.007 & 0.085 & 8.00 & 100.0 \\
\hline
\end{tabular}

Table 5. Absolute and relative contributions of biometric variables to the two principal components resulting from multivariate analysis of $P$. moniliformis seeds analysed with digital imaging.

\begin{tabular}{lcccc}
\hline \multirow{2}{*}{ Variable } & \multicolumn{2}{c}{$\begin{array}{c}\text { Principal } \\
\text { component 1 }\end{array}$} & \multicolumn{2}{c}{$\begin{array}{c}\text { Principal } \\
\text { component 2 }\end{array}$} \\
\cline { 2 - 5 } & --- & \% & --- & $\%$ \\
\hline Area & 0.48 & 19.22 & 0.12 & 4.66 \\
Perimeter & 0.49 & 19.40 & -0.19 & 7.48 \\
\hline Circularity & -0.19 & 7.60 & 0.45 & 17.55 \\
Length & 0.45 & 17.83 & -0.15 & 5.75 \\
Width & 0.48 & 19.08 & 0.24 & 9.23 \\
Aspect ratio & -0.14 & 5.59 & -0.49 & 19.32 \\
Roundness & 0.14 & 5.49 & 0.49 & 19.15 \\
Solidity & -0.15 & 5.80 & 0.43 & 16.87 \\
Total & 2.52 & 100.0 & 2.56 & 100.0 \\
\hline
\end{tabular}

main components, according to the level of phenotypic similarity between the clustered trees (Figure 3). The grouping of individuals showed the formation of five distinct groups for the analysis of the principal components and the Euclidean distance (Figures 4 and 5) at the $60 \%$ cutoff level by the UPGMA model (Figure 5), limiting the grouping before convergence between individuals or the formation of isolated groups. Thus, the first two principal components were responsible for the biometric variation observed for seeds of this species, evidenced by the hierarchical dendrogram (Figure 5).

The first three groups concentrated $88 \%$ of the individuals, while groups IV and V had 6\% each. Groups I, II and III represented 18,36 and $33 \%$ of the individuals, respectively (Figure 5); individuals 4 and $10(0.259)$ were the closest ones and individuals 11 and 27 (9.151) the most distant ones according to the Euclidean distance matrix. Therefore, for conservation or genetic improvement, one should choose the most divergent individuals for seed collection and between localities of origin.

The methods of clustering and multivariate principal component analysis using seed morphological descriptors are adequate. They can be accurate to verify the existence of genetic diversity and similarity between genotypes, in addition to synthesising the number of variables to facilitate interpretation as required of the researcher (Lúcio et al., 2015).

The high variability observed among $P$. moniliformis individuals can be attributed to the reproductive biology of the species, which has a self-incompatible and andromon allogamous reproduction system (Ferreira, 2009). In addition, it is characterized by high yields of hermaphrodite

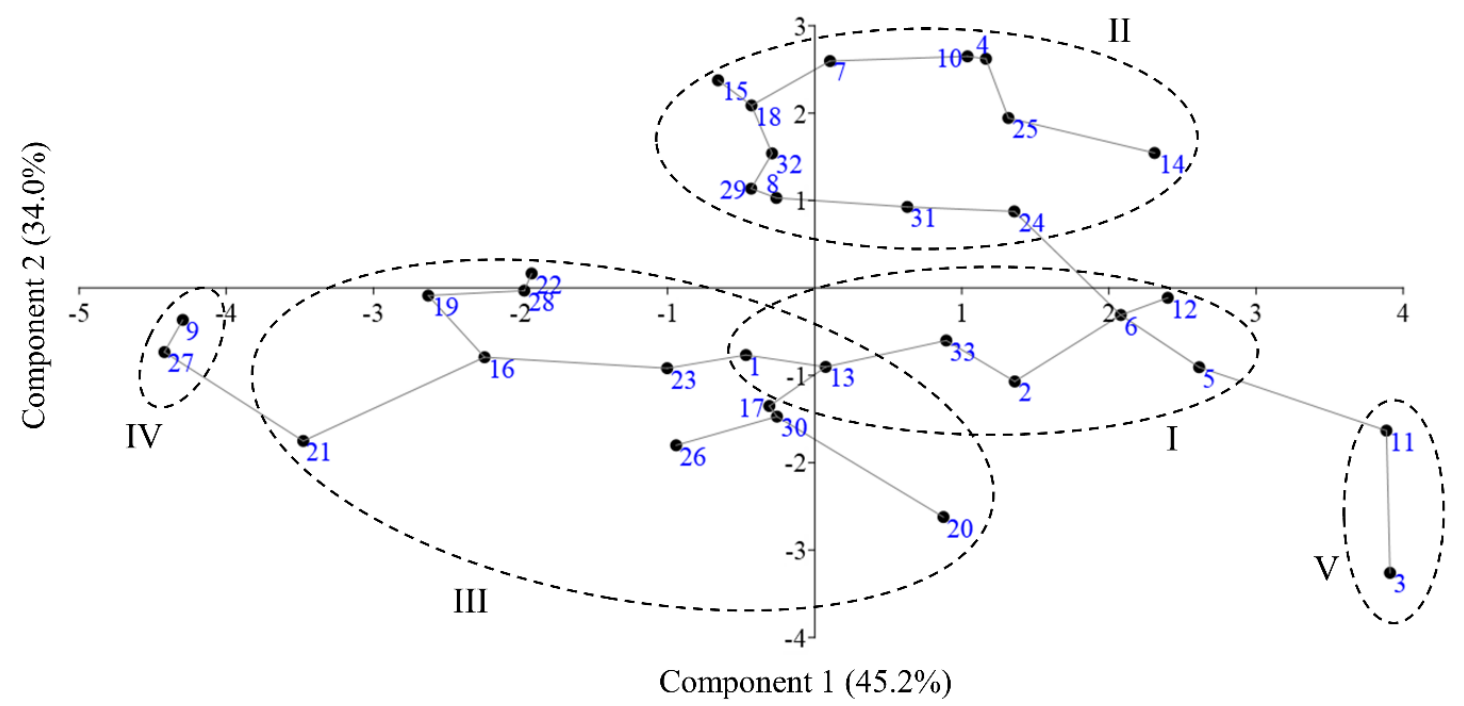

Figure 4. P. moniliformis individuals based on multivariate analysis of principal components obtained by digitally analysed seed biometrics from Macaíba (1-19) and Mossoró (20-33) localities, Rio Grande do Norte State, Brazil (Roman numerals indicate groups formation and lines between adult trees indicate the level of similarity). 


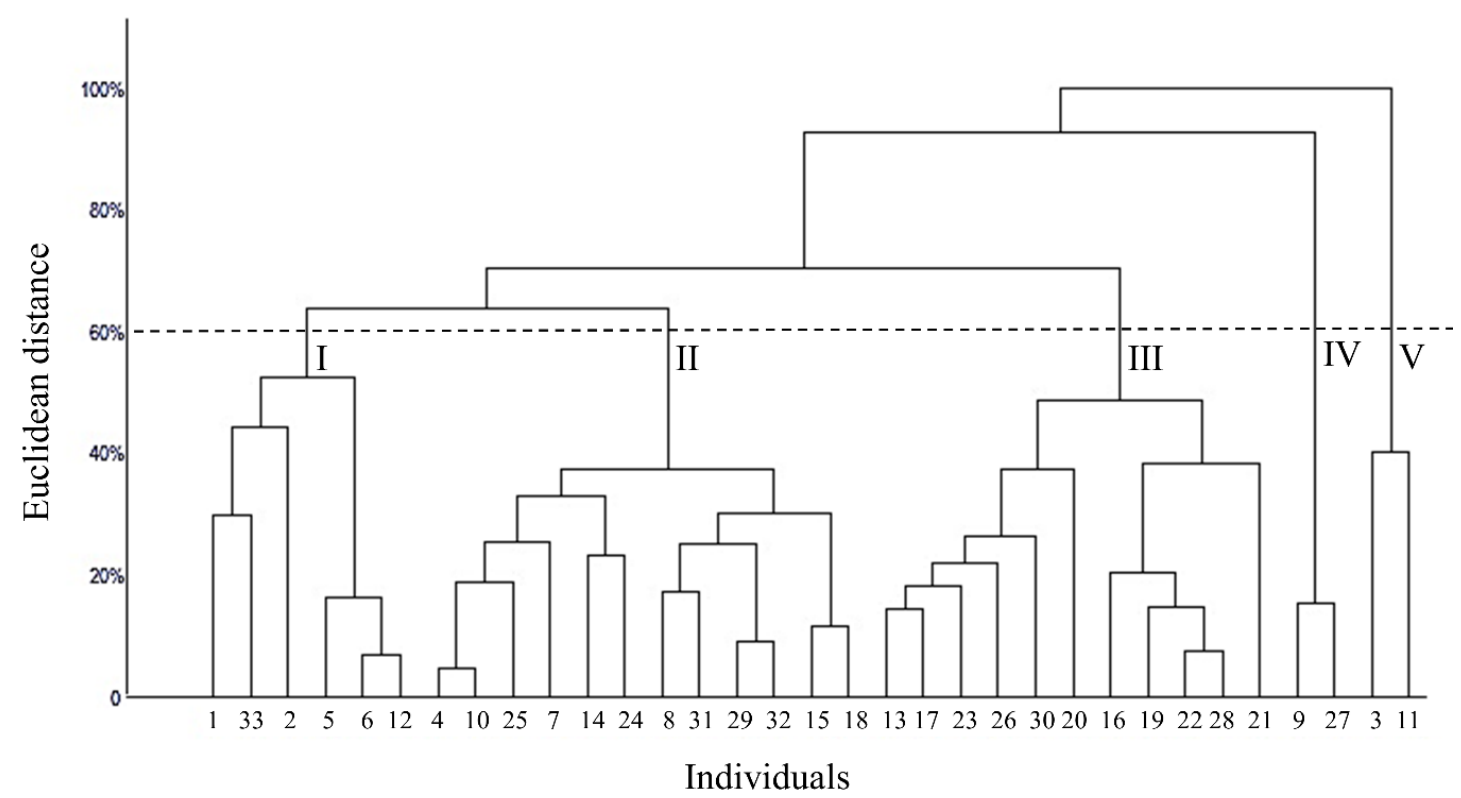

Figure 5. Euclidean distance dendrogram between $P$. moniliformis individuals based on biometric aspects of seeds analysed with digital imaging from Macaíba (1-19) and Mossoró (20-33) localities, Rio Grande do Norte State, Brazil (Roman numerals indicate groups formation at the $60 \%$ cutoff level).

and staminate flowers, a large number of pollen grains, predominance of entomological pollination, high seed yield and dehiscent dispersion (Ferreira, 2009). These characteristics imply reproduction and propagation efficiency, increasing the genetic diversity of the species among close individuals.

The biometric seed descriptors evidenced the existence of genetic divergence among $P$. moniliformis individuals. The technique used confirmed the contribution that image analysis can make to the seed industry (Varma et al., 2013) and how these methods will routinely be used to accurately assess the physical, sanitary, physiological and biochemical characteristics of seeds (Rahman \& Cho, 2016). However, further studies with molecular markers and progeny tests are necessary to confirm if the biometric changes observed for this species are due to genetic or environmental factors.

\section{Conclusions}

Digital image processing is efficient in detecting biometric differences among adult trees which vary in the morphological and biometric aspects.

The biometric variables quantified using digital images are efficient in the distinction of the adult trees. For this reason, they are important morphological markers that can aid in the differentiation of genotypes of $P$. moniliformis and contribute to studies of genetic divergence.

\section{Acknowledgements}

This study was financed in part by the Coordenação de Aperfeiçoamento de Pessoal de Nível Superior - Brazil (CAPES) - Finance Code 001.

\section{Literature Cited}

Alves, M.J.; Moura, A.K.S.; Costa, L.M.; Araújo, E.J.F.; Sousa, G.M.; Costa, N.D.J.; Ferreira, P.M.P.; Silva, J.N.; Pessoa, C.; Lima, S.G.; Citó, A.M.G.L. Teor de fenóis e flavonoides, atividades antioxidante e citotóxica das folhas, frutos, cascas dos frutos e sementes de Piptadenia moniliformis Benth (Leguminosae -Mimosoideae). Boletín Latinoamericano y del Caribe de Plantas Medicinales y Aromáticas, v.13, n.5, p.466-476, 2014. http://www.revistas. usach.cl/ojs/index.php/blacpma/article/view/1785/1664. 11 Set. 2019.

Ayres, M.; Ayres Júnior, M.; Ayres, D.L.; Santos, A.D. BioEstat 5.0 - aplicações estatísticas na área das ciências biológicas e biomédicas. 5 ed. Belém: ONG Mamiraua, 2007. 364p.

Azerêdo, G.A.; Paula, R.C.; Valeri, S.V. Determining the viability of Piptadenia moniliformis Benth seeds with the tetrazolium test. Journal of Seed Science, v.33, n.1, p.61-68, 2011. https://doi. org/10.1590/S0101-31222011000100007.

Bacchetta, G.; Grillo, O.; Mattana, E.; Venora, G. Morpho-colorimetric characterization by image analysis to identify diaspores of wild plant species. Flora, v.203, n.8, p.669-682, 2008. https://doi. org/10.1016/j.flora.2007.11.004.

Bewley, J.D.; Bradford, K.J.; Hilhorst, H.W.M.; Nonogaki, H. Seeds physiology of development, germination and dormancy. 3.ed. New York: Springer, 2013. 392p.

Costa, M.F.; Lopes, A.C.A.; Gomes, R.L.F.; Araújo, A.S.F.; Zucchi, M.I.; Pinheiro, J.B.; Valente, S.E.S. Characterization and genetic divergence of Casearia grandiflora populations in the Cerrado of Piaui state, Brazil. Floresta e Ambiente, v.23, n.3, p. 387-396, 2016. https://doi.org/10.1590/2179-8087.007115.

Cruz, C.D.; Regazzi, A.J.; Carneiro, P.C.S. Modelos biométricos aplicados ao melhoramento genético. v.1, 4.ed. Viçosa: UFV, 2012. 514p. 
Cruz; C.D.; Ferreira, F.M.; Pessoni, L.A. Biometria aplicada ao estudo da diversidade genética. Visconde do Rio Branco: Suprema, 2011. $620 p$.

Dell'Aquila, A. Computerised seed imaging: a new tool to evaluate germination quality. Communications in Biometry and Crop Science, v.1, n.1, p.20-31, 2006. http://agrobiol.sggw.waw. pl/ cbcs/articles/CBCS_1_1_3.pdf. 22 Abr. 2018.

Ferreira, M.H.S. Polinização e mirmecofilia em Pityrocarpa moniliformis (Benth.) Luckow \& Jobson (Leguminosae: Mimosoideae). Feira de Santana: Universidade Estadual de Feira de Santana, 2009. 160p. Dissertação Mestrado. http://www. ppgbot.uefs.br/teses-dissertacoes/downloads/88/polinizacaoe-mirmecofilia-em-pityrocarpa-moniliformis-benth-luckowjobson-leguminosae-mimosoideae-.pdf. 22 Jun. 2018.

Ferreira, T.; Rasband, W. ImageJ: user guide - IJ 1.46r. 2012. 198p. https://imagej.nih.gov/ij/docs/guide/user-guide.pdf. 22 Abr. 2018.

Hammer, O.; Harper, A.T.D. Paleontological data analysis. Malden: Blackwell Publishing, 2008. 368p. https://doi. org/10.1002/9780470750711.

Jesus, M.C.; Borges, R.L.B.; Souza, B.A.; Brandão, H.N.; Santos, F.A.R. A study of pollen from light honeys produced in Piauí State, Brazil. Palynology, v.39, n.1, p.110-124, 2015. https://doi.org/10. 1080/01916122.2014.942440.

Kaiser, H.F. The application of electronic computers to factor analysis. Educational and Psychological Measurement. v.20, n.1, p.141151, 1960. http://dx.doi.org/10.1177/001316446002000116.

Lúcio, A.D.C.; Fortes, F.O.; Storck, L.; Cargnelutti Filho, A. A multivariate approach to analyse native forest tree species seeds. Cerne, v.12, n.1, p.27-37, 2015. http://cerne.ufla.br/site/index.php/CERNE/ article/view/404. 22 Abr. 2018.

Maia-Silva, C.; Silva, C.I.; Hrncir, M.; Queiroz, R.T.; ImperatrizFonseca, V.L. Guia de Plantas - visitadas por abelhas na Caatinga. Fortaleza: Fundação Brasil Cidadão, 2012. 99p.

Maranho, A.S.; Soares, I.D.; Guimarães, A.V.P.J. Biometrics measures of fruits-seeds and seedling emergence of Cordia alliodora (Ruiz \& Pav.) Cham. in different substrates and sowing depths. Revista Biociências, v.20, n.1, p.56-62, 2014. http://periodicos.unitau.br/ojs/index.php/ biociencias/article/viewFile/1823/1524. 11 Set. 2019.

Marcos Filho, J. Seed physiology of cultivated plants. 2.ed. Piracicaba: FEALQ, 2016. 616p.

Medina, W.; Skurtys, O.; Aguilera, J.M. Study on image analysis application for identification quinoa seeds (Chenopodium quinoa Willd) geographical provenance. LWT - Food Science and Technology, v.43, n.2, p.238-246, 2010. https://doi.org/10.1016/j. Iwt.2009.07.010.
Menegatti, R.D.; Mantovani, A.; Navroski, M.C.; Souza, A.G. Genetic divergence among provenances of Mimosa scabrella Benth. based on seed analysis. Revista Brasileira de Ciências Agrárias, v.12, n.3, p.366-371, 2017. https://doi.org/10.5039/agraria. v12i3a5449.

Orrù, M.; Grillo, O.; Lovi, G.; Venora, G.; Bacchetta, G. Morphological characterisation of Vitis vinifera $\mathrm{L}$. seeds by image analysis and comparison with archaeological remains. Vegetation History and Archaeobotany, v.22, n.231, p.231-242, 2013. https://doi. org/10.1007/s00334-012-0362-2.

Peñaloza, P.; Durán, J.M.; Association between biometric characteristics of tomato seeds and seedling growth and development. Electronic Journal of Biotechnology, v.18, n.4, p.267-272, 2015. https://doi.org/10.1016/j.ejbt.2015.04.003.

Rahman, A.; Cho, B.W. Assessment of seed quality using nondestructive measurement techniques: a review. Seed Science Research, v.26, p.285-305, 2016. https://doi.org/10.1017/ S0960258516000234.

Sebbenn, A.M. Número de árvores matrizes e conceitos genéticos na coleta de sementes para reflorestamentos com espécies nativas. Revista do Instituto Florestal, v.14, n.2. p.115-132, 2002. https:// smastr16.blob.core.windows.net/iflorestal/ifref/RIF14-2/RIF142_115-132.pdf. 11 Set. 2019.

Souza, C.L.M.; Souza, M.O.; Oliveira, R.S.; Nascimento, M.N.; Pelacani, C.R. Biometric characteristics of fruits and physiological characterization of seeds of Physalis species (Solanaceae). Revista Brasileira de Ciências Agrárias, v.12, n.3, p.277-282, 2017. https://doi.org/10.5039/agraria.v12i3a5447.

Ucchesu, M.; Orrù, M.; Grillo, O.; Venora, G.; Paglietti, G.; Ardu, A.; Bacchetta, G. Predictive method for correct identification of archaeological charred grape seeds: support for advances in knowledge of grape domestication Process. Plos One, v.11, n.2, p.1-18, 2016. https://doi.org/10.1371/journal.pone.0149814.

Varma, V.S.; Durga, K.; Keshavulu, K. Seed image analysis: its applications in seed science research. International Research Journal of Agricultural Sciences, v.1, n.2, p.3036, 2013. http://advancedresearchjournals.org/download. php?id=558914577974418135. pdf\&type=application/pdf. 22 Abr. 2018.

Vieira, F.A.; Gusmão, E. Biometry, storage of seeds, and seedling emergence of Talisia esculenta Radlk. (Sapindaceae). Ciência e Agrotecnologia, v.32, n.4, p.1073-1079, 2008. https://doi. org/10.1590/S1413-70542008000400006. 